\title{
MENGAPA MENGHARGAI IBU ? Analisis Psikologi Indijinus pada Pelajar Sekolah Menengah Atas di Provinsi Riau
}

\author{
Ami Widyastuti, Ricca Angreini Munthe \\ Universitas Islam Negeri Sultan Syarif Kasim Riau, Indonesia \\ ami.widyastuti@uin-suska.ac.id
}

\begin{abstract}
$A B S T R A C T$
The purpose of this study was to explore the reason why senior high school students appreciated their mother. Research methodology is descriptive qualitative. Using the survey technique, data is collected with questionnaires consisting of open questions developed by Kim (2006) and adapted by the Indigenous Psychology Center (CIPP). This questionnaire was filled by 224 Senior High School in Riau Province. Data analize by categorization based on similar theme, then respon frequencies in theme group cross tab with sex. The result show that there are 7 reasons children respect their mother: (1) the best person (31,9\%); (2) the significant person (21,8\%), (3) lover (17,9\%), (4) care taker (13,0\%); (5) the backbone of the family (8,3\%), (6) role model (5,6\%) and (7) motivator (1,9\%). This result could be a reference for women who will be a mother, so she will be appreciated by their children.
\end{abstract}

Keywords: Children Education; Indigenous Psychology; Mother's Care

\begin{abstract}
ABSTRAK
Tujuan penelitian adalah mencari tahu alasan menghargai ibu dari perspektif anak. Jenis penelitian kualitatif deskriptif dengan menggunakan pendekatan Indigenous Psychology, yang melihat dari sudut pandang budaya lokal setiap fenomena sesuai konteks terkait.Menggunakan metode Survey, data dikumpulkan dengan kuesionerberisi pertanyaan terbuka dan tertutup yang dikembangkan oleh Kim (2006) dan telah disesuaikan dengan Center for Indigeonus Psychology (CIPP) Fakultas Psikologi UIN Sultan Syarif Kasim Riau. Responden penelitian adalah 224 pelajar Sekolah Menengah Atas di Propinsi Riau. Data dianalisis dengan pengkategorisasian berdasarkan persamaan tema, ditabulasi silang dengan jenis kelamin responden. Hasil penelitian menemukan bahwa ada 7 alasan seseorang menghargai sosok ibunya yaitu : (1) orang yang terbaik $(31,9 \%)$, (2) orang penting/kunci $(21,8 \% 0$, (3) pecinta $(17,9 \%)$, (4) penanggung jawab $(13,0 \%)$, (5) tulang punggung keluarga $(8,3 \%)$, (6) model perilaku $(5,6 \%)$, dan (7) pemberi motivasi $(1,9 \%)$. Temuan ini perlu dijadikan referensi bagi calon ibu agar dihargai anak.
\end{abstract}

Kata Kunci: Pendidikan Anak; Pengasuhan Ibu; Psikologi Indijenus 


\section{PENDAHULUAN}

Beberapa tahun terakhir penelitian mengenai relasi orangtua dan anak menjadi perhatian dalam kajian psikologi. Penelitian mengenai pola pengasuhan merupakan salah satu bentuk perhatian mengenai pentingnya peran orangtua dalam mengasuh dan mendidik anak.

Orang tua memiliki peran yang sangat penting dalam kehidupan anak. Salah satu cara untuk mengkonseptualisasikan peran orangtua adalah memandang orangtua sebagai manajer kehidupan anak. Pada masa bayi, hal ini mungkin meliputi membawa anak ke dokter dan mengatur pengasuhan anak. Pada masa kanak-kanak, peran manajerial berupa menentukan preschool mana yang harus dimasuki anak, mengarahkan anak agar memakai pakaian yang bersih dan menjauhkan mainan, dan menyusun aktivitas anak setelah sekolah. Pada masa dewasa, peran manajerial mencakup menetapkan jam malam dan memantau kuliah dan minat karier anak (Santrock, 2007).

Peran manajerial penting dalam perkembangan sosioemosional anak. Sebagai manajer, orangtua boleh mengatur kesempatan anak untuk melakukan kontak sosial dengan teman sebaya, teman dan orang dewasa. Orangtua memainkan peran penting dalam membantu perkembangan anak dengan memulai kontak antara anak dengan teman bermainya yang potensial. Anak dari orangtua yang mengatur kontak dengan teman sebaya memiliki jumlah teman bermain di luar sekolah yang lebih banyak daripada anak dari orangtua yang kurang efektif dalam mengatur kontak ini. Aspek penting lainnya dalam peran manajerial adalah pemantauan efektif atas anak. Hal tersebut sangat penting ketika anak-anak memasuki masa dewasa. Pemantauan meliputi mengawasi pilihan anak tentang tempat social, aktivitas dan teman. Kurangnya pemantauan orangtua berkaitan dengan kenakalan remaja daripada faktor pengasuhan lainnya (Santrock, 2007).

Di dalam keluarga salah satu individu yang berperan sangat penting dalam pengasuhan anak adalah ibu. Ibu memainkan peran yang sangat penting dalam perkembangan anak. Pada umumnya, ibu merupakan orang yang pertama dan segera dalam memenuhi kebutuhan anak. Ketika ibu dengan segera memenuhi kebutuhan anak maka anak akan mengembangkan rasa percaya, namun sebaliknya ketika ibu tidak segera memenuhi kebutuhan anak maka anak akan 
mengembangkan rasa tidak percaya. Hal senada diungkapkan oleh Holmes and Cavalo (dalam Lestari, Faturochman, Kim, 2010) bahwa anak mengembangkan rasa percaya dari pengasuhnya yang biasanya dilakukan oleh Ibu. Perkembangan rasa percaya dalam suatu hubungan biasanya terjadi dalam proseses yang melalui tahapan yang melibatkan interaksi sosial dan pengalaman dengan seseorang yang membuat orang tersebut tergantung khususnya pada situasi yang memuaskan ketika orang tersebut memenuhi kebutuhannya.

Ibu secara etimologi berarti (1) wanita yang telah melahirkan seseorang, (2) sebutan untuk wanita yang telah bersuami, (3) panggilan yang takzim kepada wanita baik yang sudah bersuami maupun yang belum (Kamus Besar Bahasa Indonesia, 2007). Kata Ibu secara terminologi menurut Abu Al'Aina Al Mardhiyah adalah menerangkan pada status mulia yang disandang oleh wanita normal, dimana ibu menjadi tumpuan harapan penerus generasi (Abu Al'Aina Al Mardhiyah, 1996). Sementara Sobur (1986) mengatakan bahwa ibu adalah orang pertama yang dikejar anak untuk mendapatkan perhatian, pengharapan, dan kasih sayang, karena merupakan orang pertama yang dikenal anak

Fraiberg (dalam Berns, 2007) menyatakan bahwa ibu adalah pengasuh yang utama bagi anak. Pengasuhan ibu yang baik juga berdampak baik terhadap anak. Studi tersebut dimulai dari studi mengenai kelekatan anak terhadap pengasuh utama, yaitu orang yang selalu berada disisi anak, membuat anak merasa nyaman, memberi makan kepada anak, dan bermain bersama anak. Ibu merupakan orang yang paling banyak menghabiskan waktu dalam aktivitas rutin perawatan anak (Park, dalam Mallers, Neupert, Charles, \& Almeida, 2010) dan merupakan sumber utama dalam kenyamanan dan keamanan fisik anak (Boumrind, dalam Mallers, dkk, 2010).

Peran Ibu tidak hanya dilakukan pada saat kana-kanak. Pada masa remaja, Ibu juga terlibat dan berperan dalam kehidupan anak. Anyikwa \& Obidike (2012) menemukan bahwa ibu biasanya sering terlibat aktif dalam pendidikan anak dalam hal ini Ibu berperan menjadi penasehat bagi pendidikan anak dan berusaha mengidentifikasi dan memberikan kesempatan pada anak untuk belajar diluar sekolah. Ibu memainkan peran yang sangat kuat dalam keamanan dan kesehatan emosi anak (Mallers, dkk, 2010).

Ibu memiliki cinta yang tak ada bandingannya. Setiap manusia yang memiliki ibu di dunia ini dapat merasakan betapa ibu mencintainya. Cinta seorang ibu kepada anaknya 
menunjukkan cinta tanpa syarat terhadap hidup dan kebutuhna-kebutuhan sang anak (Fromm, 1956). Akan tetapi sebenarnya hubungan ibu dengan anak bukanlah hubungan yang seimbang, dimana anak akan selalu memerlukan segala bantuan sementara ibu siap memberikan segalanya bagi anak. Formm (1956) berpendapat bahwa cinta ibu yang demikian disebut sebagai ciri altruistik yaitu saat ibu tidak mementingkan dirinya sendiri dan jenis cinta ini merupakan jenis cinta tertinggi yang memiliki ikatan emosional paling luhur.

Pengaruh positif dalam perkembangan anak dapat terjadi selama ibu menjalankan fungsi dan perannya. Anak belajar mengenal dan memahami nilai-nilai melalui bimbingan dan arahan ibu. Perilaku ibu juga dapat menjadi model sehingga ditiru oleh anak dan dapat menjadi karakter atau kepribadian yang tertanam dalam diri anak. Hal tersebut didukung oleh pendapat Sahin (2014) yang menyatakan bahwa sikap dan perilaku ibu akan berdampak pada kepribadian anak. Hubungan yang hangat dan penuh afeksi akan membentuk pribadi yang sehat pada anak dan juga lebih berdampak positif bagi ibu.

Diener and Diener (2008) menyatakan bahwa hubungan dekat secara emosional dengan ibu telah dibangun dari bayi. Kedekatan emosional ini membuat individu merasa aman, nyaman dan dipedulikan. Ibu mendidik, mengajari nilai-nilai dan menjadi penolong pada saat individu membutuhkan pertolongan. Perasaan mencintai dan dicintai tersebut membuat individu tumbuh dan berkembang menjadi diri sendiri. Individu tumbuh mulai dari kanakkanak hingga dewasa hanya melalui mentoring dan dukungan dari orangtua.

Kurangnya peran ibu dalam pemenuhan kebutuhan dasar anak tentunya memiliki dampak yang kurang baik bagi peran ibu dalam pemenuhan kebutuhan dasar anak. Apabila peran ibu tidak berhasil maka anak akan mengalami gangguan pertumbuhan dan perkembangan dan apabila anak mengalami keterlambatan dalam pertumbuhan dan perkembangannya akan sulit terdeteksi,dan apabila peran ibu berhasil maka anak dapat bertumbuh dan berkembang sesuai dengan usianya (Werdiningsih dan Astarani, 2012)

Penelitian ini berfokus pada pelaksanaan peran dan fungsi ibu dalam keluarga dilihat dari perspektif anak. Deskripsi di atas menunjukkan bahwa penelitian terdahulu lebih banyak berfokus pada penelitian mengenai peran ibu terhadap perkembangan anak, namun belum ada penelitian yang mengkaji mengenai perspektif anak mengenai alasan mengapa mereka menghargai ibu. Apakah mereka beranggapan bahwa alasan mereka menghargai ibu sesuai 
dengan peran yang dijalankan oleh Ibu? Meskipun terdapat teori yang menyatakan bahwa deskripsi anak mengenai apa yang dilakukan oleh orangtua menunjukkan berbagai peran yang dilakukan oleh orangtua seperti melindungi anak, memberikan dukungan emosional dan finansial, memonitor atau mengatur perilaku anak, memandu dan dan mengedukasi anak, serta memfasilitasi anak untuk mandiri (Nixon, 2010). Namun, dapat saja perspektif anak berbeda dengan apa yang dilakukan oleh ibu. Misalnya, ketika ibu menjalankan perannya sebagai individu yang memberikan pendidikan dan penanaman nilai moral dengan melarang anak keluar malam bersama temannya, bisa saja anak menganggap bahwa ibu adalah orang yang tidak memahami anak bukan individu yang mengajarkannya tentang nilai-nilai moral. Dengan demikian, perlu untuk diteliti apa alasan anak menghargai ibu mereka? Apakah anak dapat memahami apa yang telah dilakukan oleh ibu dalam kehidupannya?

\section{METODE}

Penelitian ini adalah penelitian survey dengan metode analisis kualitatif deskriptif. Subjek penelitian adalah remaja sekolah menengah atas yang ada di Pekanbaru, Riau, berjumlah 224 orang siswa SMA di Pekanbaru. Teknik pengambilan sampling menggunakan teknik purposive sampling (Creswell, 2012). Pada teknik ini tidak semua unsur atau elemen populasi mempunyai kesempatan sama untuk bisa dipilih menjadi sampel. Unsur populasi yang terpilih menjadi sampel bisa disebabkan karena kebetulan atau karena faktor lain yang sudah ditentukan oleh peneliti. Pada penelitian ini kriteria subjek penelitian adalah remaja sekolah menengah atas yang ada di Pekanbaru, Riau dengan rentang usia 15-18 tahun dan belum menikah, dibesarkan oleh ibu atau ayah dan ibu. Ketentuan jumlah sampel berdasarkan saturasi (Creswell, 2012), artinya peneliti akan berhenti menambah subjek penelitian jika mendapatkan data yang sama secara terus menerus pada partisipan yang berbeda-beda.

Metode pengumpulan data yang digunakan adalah kuesioner dengan pertanyaan tertutup, yaitu "Apakah anda menghargai Ibu?" kemudian dilanjutkan dengan pertanyaan terbuka "Tuliskan alasan mengapa anda menghargai Ibu?"

Instrumen penelitian ini menggunakan kuesioner dengan pertanyaan terbuka yang telah dikembangkan oleh Kim (2008) dan kemudian disusun kembali oleh Center for 
Indigenous Psychology (CCIP) FakultasPsikologi UGM dan Center for Indigenous Psychology (CCIP) FakultasPsikologi UIN Sultan Syarif Kasim Riau yang disesuaikan dengan kebutuhan penelitian di Indonesia khususnya di Pekanbaru, Riau. Jawaban subjek dikategorikan dalam kategori kecil dan dilakukan validasi oleh tim Center for Indigenous Psychology (CCIP) FakultasPsikologi UIN Sultan Syarif Kasim Riau yang terdiri dari dosen dan mahasiswa yang menjadi asisten Center for Indigenous Psychology (CCIP) FakultasPsikologi UIN Sultan Syarif Kasim Riau.

Analisis data menggunakan pendekatan Indigenous Psychology, dengan koding, kategorisasi, dan frekuensi. Dimulai dengan mengkoding seluruh jawaban subjek, kemudian mengkategorisasikan jawaban-jawaban tersebut dalam kategori-kategori jawaban yang sama, setelah didapatkan kategori-kategori jawaban selanjutnya dicari frekuensi dari jawabanjawaban subjek tersebut dengan bantuan program software Nvivo 10. Nvivo mampu menghasilkan kategorisasi yang di susun oleh peneliti, namun penentuan kategori dibuat berdasarkan teori dan validasi oleh rekansejawat.

\section{HASIL PENELITIAN}

Untuk mendapatkan kesimpulan tentang alasan-alasan apakah dan mengapa anakanak Sekolah Menengah Atas di Pekanbaru menghargai ibunya, dapat dilihat pada tabeltabel berikut ini.

Table 1: Proporsi Responden Penelitian

\begin{tabular}{|c|l|c|c|}
\hline No & \multicolumn{1}{|c|}{ Jenis Kelamin } & Jumlah Sampel & Proporsi(\%) \\
\hline 1 & Perempuan & 142 & 63,39 \\
\hline 2 & Laki - Laki & 82 & 36,61 \\
\hline
\end{tabular}




\begin{tabular}{|c|c|c|}
\hline Jumlah & 224 & 100 \\
\hline
\end{tabular}

Sumber: Data Olaban Penelitian 2019

Berdasarkan tabel 1 diatas dapat diketahui bahwa jumlah responden yang terbesasr adalah perempuan sebanyak 142 orang atau sebesar 63,39\% dari total 224 responden penelitian. Responden dalam penelitian ini adalah Pelajar Sekolah Menengah Atas yang memiliki Ibu atau Ayah dan Ibu dengan rentang usia bervariasi antara 15 sampai dengan 18 tahun dan berdomisili di Pekanbaru.

Table 2: Tanggapan Responden Tentang Apakah Menghargai Ibu

\begin{tabular}{|c|c|c|}
\hline $\begin{array}{l}\text { Apakah Anda } \\
\text { Menghargai Ibu }\end{array}$ & Frekuensi & $\begin{array}{c}\text { Persentase } \\
(\%)\end{array}$ \\
\hline $\mathrm{Ya}$ & 224 & 224 \\
\hline Tidak & 0 & 0 \\
\hline Total & 224 & 224 \\
\hline
\end{tabular}

Sumber: Data Olahan Penelitian 2019

Dari tabel 2 di atas dapat diketahui bahwa seluruh responden penelitian memiliki pemikiran untuk menghargai ibu. Tidak ada seorang pun dari responden yang tidak menghargai Ibu.

Mengenai alasan responden mengapa menghargai ibu, dapat dilihat pada table berikut:

Tabel 3: Tanggapan Responden Tentang Alasan Mengapa Menghargai Ibu

\begin{tabular}{|l|c|c|}
\hline \multicolumn{1}{|c|}{ Alasan Menghargai Ibu } & Frekuensi & Persentase (\%) \\
\hline Ibu adalah yang terbaik & 71 & 31,70 \\
\hline Ibu adalah orang yang penting (meliputi orang yang & 49 & 21,88 \\
\hline
\end{tabular}




\begin{tabular}{|l|c|c|}
\hline penting dan memberikan berkah) & 40 & 17,86 \\
\hline $\begin{array}{l}\text { Ibu mencintai/menyayangi anak (meliputi hubungan yang } \\
\text { sehat dan mencintai) }\end{array}$ & 29 & 12,95 \\
\hline Ibu orang yang merawat anak & 18 & 8,03 \\
\hline $\begin{array}{l}\text { Ibu adalah tulang punggung keluarga (meliputi tulang } \\
\text { punggung keluarga dan pekerja di rumah) }\end{array}$ & 13 & 5,80 \\
\hline $\begin{array}{l}\text { Ibu adalah role model (meliputi sosok wanita kuat dan } \\
\text { beriman) }\end{array}$ & 4 & 1,78 \\
\hline Ibu adalah motivator & 224 & 100 \\
\hline
\end{tabular}

Sumber: Data Olahan Penelitian 2019

Berdasarkan data terhadap jawaban responden mengapa mereka menghargai Ibu, ditemukan bahwa ada tujuh alasan mengapa seseorang menghargai ibu. Alasan-alasan tersebut adalah karena ibu: (1) adalah orang yang terbaik (31,70\%); (2) orang yang penting $(21,88 \%)$ meliputi orang yang penting dan memberikan berkah; (3) mencintai/menyayangi $(17,86 \%)$ meliputi hubungan yang sehat dan mencintai; (4) merawat (12,95\%); (5) tulang punggung keluarga (8,03\%) meliputi tulang punggung keluarga dan pekerja di rumah; (6) role model (5,80\%) meliputi contoh sosok wanita yang kuat dan beriman; dan (7) motivator $(1,78 \%)$.

Dari hasil analisis jawaban responden tersebut maka dapat disimpulkan bahwa alasan terbesar mengapa seorang anak menghargai ibu adalah karena menurut mereka ibu merupakan sosok terbaik dan penting dalam hidup mereka. Mereka menyayangi dan mencintai ibu karena ibu memberikan cinta dan kasih sayang kepada mereka, dan oleh karena itu sosok seorang Ibu selayaknya mereka hargai.

\section{PEMBAHASAN}

Hasil penelitian ini menemukan bahwa seorang anak menghargai ibunya dengan alasan yang berbeda-beda. Alasan yang paling utamabagi mereka untuk menghargai ibu adalah karena ibu merupakan individu yang terbaik dalam kehidupan mereka (31,70\%). Hal tersebut dapat terjadi mengingat begitu banyak hal yang dapat dilakukan oleh ibu untuk anak. Tidak hanya 
menjalankan fungsinya sebagai seorang ibu, namun juga menjalankan fungsinya sebagai seorang istri. Santrock (2007) juga mendukung hal tersebut, dari bayi melalui masa remaja ibu lebih cenderung melakukan peran manejerial dalam pengasuhan daripada ayah.Padamasa bayi, hal ini mungkin meliputi membawa anak ke dokter dan mengatur pengasuhan anak. Pada masa kanak-kanak, peran manajerial berupa menentukan preschool mana yang harus dimasuki anak, mengarahkan anak agar memakai pakaian yang bersih dan menjauhkan mainan, dan menyusun aktivitas anak setelah sekolah. Pada masa dewasa, peran manajerial mencakup menetapkan jam malam dan memantau kuliah dan minat karier anak.

Alasan berikutnya mengapa seorang anak menghargai ibu dalam penelitian ini adalah bahwa ibu adalah orang yang penting $(21,88 \%)$. Kondisi tersebut dapat dijelaskan dengan teori kelekatan yang dipelopori oleh Bolwby, bahwa kehadiran ibu dapat membentuk pola kelekatan kepada anak. Ketika anak berada pada situasi yang asing atau perasaan tidak enak, anak akan menginginkan untuk dekat dengan figur lekatnya (biasanya ibu, namun dapat saja ayah, kakek, nenek, ataupun pengasuh). Anak dengan pola kelekatan yang tidak aman (insecure attachment) akan menangis histeris jika ditinggalkan oleh ibu hingga ibu kembali dan biasanya akan menolak dan menghindari ibu ketika ibu kembali. Anak dengan pola kelekatan aman (secure attachment) ketika ditinggal oleh ibu akan mengeksplor mainan yang ada disekitarnya dan ketika ibu kembali anak akan menunjukkan perasaan bahagia (Berns, 2007). Belsky (dalam Berns, 2007) menunjukkan bahwa anak dibawah usia 1 tahun tanpa kehadiran dan pengasuhan ibu selama 20 jam perminggu akan memiliki pola kelekatan tidak aman terhadap ibunya dan akan meningkatkan risiko masalah emosi dan perilaku ketika berada pada masa kanak-kanak serta akan menjadi agresif dikemudian hari.

Alasan ketiga yang menjelaskan mengapa seorang anak menghargai ibu adalah karena ibu mencintai/menyayangi anak (17,86\%). Ibu memberikan kasih sayang dan cinta tak tebatas kepada anak. Cinta dan kasih sayang Ibu ini layaknya benteng bagi keluarga untuk menguatkan anggota keluarga saat mereka tumbuh dan berkembang karenaanak-anak menjalani proses tumbuh dan berkembang dalam suatu lingkungan dan hubungan (Thompson, 2006). Pengalaman anak sepanjang waktu bersama orang-orang yang mengenal mereka dengan baik, serta berbagai karakteristik dan kecenderungan yang mereka pahami merupakan hal-hal pokok yang mempengaruhi perkembangan mereka (Lestari, 
2012). Berdasarkan hasil penelitian Shofiah (2014) pada anak didik pemasyarakatan dengan kasus narkoba, ditemukan bahwa anak-anak pada kasus ini tidak memiliki hubungan emosional yang mendalam antara ibu dan anak. Kualitas hubungan afeksi (kasih sayang dan cinta) antara ibu dan anak lemah. Hal ini menyebabkan anak tersebut tidak mengembangkan kelekatan yang aman dengan figur lekat (Ibu) dan oleh sebab itu membawa pengaruh negatif dalam proses perkembangan mereka. Begitu pentingnya perasaan dicintai dan disayangi ini, karena keyakinan akan rasa cinta kasih dan hubungan yang sehat dan mencintai antara ibu dan anak, membuat seorang anak memiliki kompetensi social yang baik (Both dkk dalam Parker, Rubin, Price dan DeRosier, 1995). Mereka juga akan lebih mampu membina hubungan persahabatan yang intens, interaksi harmonis, responsif, dan tidak mendominasi (Parke dan Waters dalam Parker, Rubin, Price dan DeRosier, 1995).

Alasan keempat yang muncul mengapa anak menghargai ibu adalah karena ibu yang merawat $(12,95 \%)$ dari kecil hingga dewasa. Hasil penelitian ini juga didukung oleh pendapat Fraiberg (dalam Berns, 2007) yang menyatakan bahwa ibu merupakan orang utama dalam merawat anak. Hasil penelitian ini juga menunjukkan bahwa alasan menghargai ibu karena ibu sebagai role model (5,80\%) hal tersebut didukung oleh pendapat Lestari, dkk (2010) bahwa orangtua diharapkan menjadi model bagi anak-anaknya sebagai teladan. Sebagai model orangtua seharusnya mengendalikan perilaku dan memiliki atribut yang baik.

Jika dikaitkan dengan hasil penelitian alasan ibu dihargai karena ibu adalah seorang yang merawat berkaitan dengan peranan ibu dalam kehidupan anak-anaknya. Sejak anak dilahirkan, seorang ibu selalu ada disamping anak. Ibu menyusui, memberi makan, menghibur anak saat anak sedih dan menangis. Ia juga peka terhadap perubahan suasana hati sang anak. Seringkali saat seorang anak belum mampu berbicara dengan lancar, ibu adalah seseorang yang paling mengerti apa yang diucapkan sang anak, bahkan kadang kala hanya ia satu-satunya orang yang paling mengerti. Ibu senantiasa mengasuh anak dan rela berkorban untuk anaknya baik waktu istirahat maupun sibuk.

Ibu sebagai tulang punggung keluarga menjadi alasan bagi sebanyak (8,03\%) responden penelitian mengapa mereka menghargai seorang ibu. Ibu yang menjadi tulang punggung keluarga dan pekerja di rumahtidak hanya bekerja mencari uang demi menjamin 
kehidupan anak-anaknya agar dapat memenuhi kebutuhan anak akan makanan dan sekolah, namun masih juga harus bekerja mengerjakan pekerjaan rumah tangga harian. Meningkatnya biaya hidup rumah tangga, pendapatan suami yang tidak mencukupi, dan kondisi perekonomian yang tidak stabil membuat seorang ibu turut berperan serta dalam meringankan beban keluarga dengan membantu mencari penghasilan. Berdasarkan hasil penelitian yang dilakukan oleh Nesneri dan Museliza pada tahun 2014 di Pekanbaru, ditemukan bahwa kontribusi penghasilan ibu rumah tangga yang bekerja untuk pendapatan keluarga cukup besar yaitu sebesar 51 - 70\% dari total keseluruhan pendapatan keluarga. Hal ini bisa dimaknai juga bahwa jumlah pendapatan yang dihasilkan ibu jauh lebih besar daripada pendapatan Ayah sebagai kepala keluarga, dan oleh sebab itu ibu menjadi tulang punggung bagi keluarga.

Ibu sebagai seorang role model, memberikan contoh dan menjadi model bagi anakanaknya dalam bertindak dan perilaku. Seringkali ia menjadi pembimbing anak dalam menjalani kehidupan. Ibu memberikan contoh dan membimbing serta menjaga anak dari keburukan dan terbentuklah pribadi yang sholeh. Keteladanan dalam pendidikan merupakan metode yang berpengaruh dan terbukti paling berhasil dalam mempersiapkan dan membentuk aspek moral, spiritual, dan etos sosial anak (Nashih, 1999). Pembiasaan dan keteladanan mempunyai hubungan erat dalam proses identifikasi sehingga anak senantiasa menjadikan orangtua sebagai contoh model atau tokoh identifikasi dimana sikap dan perilaku yang dilakukan orang tua selalu ditiru oleh anak.

Penelitian ini juga menunjukkan bahwa alasan menghargai ibu karena ibu merupakan motivator (1,78\%). Senada dengan pendapat Lestari, dkk (2010) Orangtua diharapkan membantu anaknya dalam keterbatasan kemampuan yang dimiliki anaknya.

Tugas seorang ibu sungguh berat dan mulia. Pada beberapa kebudayaan, khususnya Melayu, seorang ibu diharapkan mengambil peran sebagai pendidik dan pengatur rumah tangga. Peran dan tugas ibu dalam keluarga ini sangat penting bagi terwujudnya rumah tangga sakinah, yaitu keluarga yang sehat dan bahagia. Ibu sebagai tulang punggung keluarga, merupakan bentuk nyata andil perempuan dalam sektor kehidupan. Peran serta aktif perempuan dalam sektor perekonomian dalam sudut pandang Islam sesuai dengan kajian historis Adinugraha, et.al tahun 2018. Ia menemukan bahwa gender merupakan peran, sifat dan 
perilaku yang dilekatkan dan merupakan hasil dari kontruksi social budaya. Akan tetapi Islam memuliakan kedudukan perempuan dan disetarakan dengan laki-laki. Perempuan boleh dan mampu menjadi pencari uang handal seperti Khadijah sang istri nabi yang seorang pebisnis ulung.

Tidak hanya mengelola tugas dalam rumah tangga dan pendapatan keluarga, peran ibu menjadi lebih meluas ketika anak tumbuh dan berkembang. Sepanjang rentang usia anak, ibu terlibat dalam proses tersebut. Hasil penelitian Gauvain dan Huard (1999) menemukan bahwa ibu lebih terlibat dalam peran yang berhubungan dengan perencanaan anak-anak dalam keluarga. Perannya penting dalam pendidikan dan pemilihan pekerjaan untuk anak-anak kelak, terutama ibu mendorong dan mengarahkan ke pekerjaan publik (Simpson, 2003). Dalam kegiatan pengasuhan ibu menghabiskan waktu bersama dengan anak-anak melakukan kegiatan pengasuhan seperti diskusi, memasak, mencuci. Sebaliknya ayah dalam keluarga melibatkan anak-anak dalam proyek yang maskulin di sekitar rumah seperti pekerjaan rumah (Hall \& Walker, 1995). Selain itu, ibu lebih responsif terhadap keterampilan anak-anak ketika mereka harus melakukan tugas baru dengan memberikan informasi lebih lanjut tentang tugas tersebut dan memiliki gaya instruksi dalam menjelaskan (Gauvain, Fagot, Leve, \& Kavanagh, 2002). Hal tersebut karena ibu lebih sering terlibat dan saling bertukar ide dan perasaan dengan anak-anak sehingga memiliki pengetahun yang lebih tentang keseharian serta kepentingan anak (Maccoby, 1998). Selain itu, para peneliti menemukan bahwa semakin banyak waktu yang dihabiskan anak tidak dalam perawatan ibu pada 4 tahun perawatan kehidupan, maka semakin banyak anak memperlihatkan perilaku yang bermasalah seperti ketidaktaatan serta agresifitas dan sebaliknya (Network, 2003).

Peran ibu pun tidak hanya sampai pada masa anak-anak. Pada masa remaja ibu memainkan peran yang penting yaitu sebagai teman karena lebih aktif dalam berbicara tentang topik pribadi, sehingga remaja cenderung lebih banyak berbicara dengan ibu (Waizenhofer \& Buchanan, 2004). Studi tentang gadis Afrika Amerika berusia 11-14 tahun, ibu membantu remaja perempuan membentuk niat untuk menjauhkan diri dari aktifitas seksual (Doswell, Yookyung, Braxter, 2003; Sieving \& Mcneely, 2000).

\section{SIMPULAN}


Berdasarkan hasil analisis data diketahui bahwa ada tujuh alasan mengapa seseorang menghargai ibu yaitu: (1) yang terbaik (31,9\%); (2) orang yang penting (21,8\%) meliputi orang yang penting dan memberikan berkah; (3) menyayangi (17,9\%) meliputi hubungan yang sehat dan mencintai; (4) merawat (13,0\%); (5) tulang punggung keluarga $(8,3 \%)$ meliputi tulang punggung keluarga dan pekerja di rumah; (6) role model (5,6\%) meliputi contoh sosok wanita yang kuat dan beriman; and (7) motivator $(1,9 \%)$.

Temuan penelitian ini menunjukkan bahwa Ibu adalah segalanya bagi anak. Disisi lain seorang Ibu tidak akan pernah ingin melihat anak-anaknya menderita sedikit pun. Seorang ibu juga tidak akan pernah membuat anaknya kekurangan apapun. Seorang ibu akan selalu berusaha untuk mewujudkan cita-cita anak-anaknya, bekerja bahkan sangat keras untuk memenuhi kebutuhan hidup tanpa memikirkan diri sendiri. Apapun akan dilakukan, memberikan kasih sayang hangat untuk anak-anaknya, ia juga rela kekurangan demi anaknya tidak ada satu perhatianpun yang luput dari dirinya, sebab ia yang paling dekat dengan anak-anaknya, karena hubungan emosional dan lebih banyak meluangkan waktu bersama anak. Hasil penelitian ini diharapkan memberikan referensi bagi calon ibu yang ingin dihargai anak agar menyiapkan diri sesuai dengan temuan di atas.

\section{DAFTAR PUSTAKA}

Adinugraha, H.H., et al. (2018). Kewenangan dan Kedudukan Perempuan dalam Perspektif Gender: Suatu Analisis Tinjauan Historis. Marwah: Jurnal Perempuan, Agama, dan Jender. Vol. 17, No. 1, Hal. 42-62. http://dx.doi.org/10.24014/marwah.v17i1.4515

Andayani, B. (2002). Pentingnya Budaya Menghargai dalam Keluarga. Buletin Psikologi, 1, 18.

Anyikwa, N., \& Obidike, N. (2012). Mother's Constructions of their Roles in the Literacy Education of their Children. Africa Development, 37, 57-67.

Astuti, A. W. (2013). Peran Ibu Rumah Tangga dalam Meningkatkan Kesejabteraan Keluarga. Semarang: Universitas Negeri Semarang.

A'yun, Q. (2015). Peran Orang Tua dalam Pendidikan Anak Usia Dini (Studi Kasus pada Keluarga Muslim Pelaksana Homeschooling). Surakarta: Universitas Muhammadiyah Surakarta.

Berk, L. E. (2002). Infants, Children, and Adolescents. Boston: Library of Congress. 
Berns. (2004). Child, Family, School, Community Socialization and Support. United State of America: Strawberry Field Publishing.

Berns, R. M. (2007). Child, Family, School, Community: Socialization ans Support. 7 th Edition. Canada: Thomson Wadsworth.

Brook, J. (2011). The Process of Parenting (Kedelapan ed.). Yogyakarta: Pustaka Pelajar.

Cooper, C., Halsey, C., Laurent, S., \& Sullivan, K. (2009). Ensiklopedia Perkembangan Anak. Jakarta: Erlangga.

Creswell, J. W. (2013). Qualitative Inquiry \& Research Design: Choosing Among Five Approaches. United States of America: SAGE.

, (2012). Research Design Pendekatan Kualitatif, Kuantitatif, dan Mixed. Yogyakarta: Pustaka Pelajar.

Diener, E. \& Diener, R. B. (2008). Happiness: Unlocking the Mysteries of Psychological Wealth. USA: Blackwell Publishing.

Durkin, K. (1995). Developmental Social Psychology. Massachusetts: Blackwell Publisher Inc

Erikson, E. H. (2010). Childhood and Society. Yogyakarta: Pustaka Pelajar.

Gauvain, M., \& Huard, R. D. (1999). Family Interaction, Parenting Style, and the Development of Planning: A Longitudinal Analysis. Family Psychology, 75-92.

Gauvain, M., Fagot, B., Leve, C., \& Kavanagh, K. (2002). Intstrucrion by Mothers and Fathers During Problem Solving with their Young Children. Family Psychology, 81 90.

Hall, L., \& Walker, A. (1995). Gender and Family Work in One-Parent Households. Marriage and the Family, 685-692.

Lestari, S. (2012). Psikologi Keluarga: Penanaman Nilai dan Penanganan Konflik dalam Keluarga. Jakarta: Kencana Prenada Media Group.

Lestari, S., Faturochman, \& Kim, U. (2010). Trust in Parent-Cild Relationship Among Undergraduate Student: Indigenous Psychological Analysis. Jurnal Psikologi. Volume 32, No, 2, Desember 2010: 140-152

Maccoby, E. (1998). The Twon Sexes. Harvard: Harvard.

Majid, A., \& Andayani, D. (2011). Pendidikan Karakter Perspektif Islam. Bandung: Remaja Rosdakarya Offset.

Mallers, M. H., Neupert, S. D., Charles, S. T., \& Almaeda, D. M. (2010). Perceptions of Childhood Relationships withMother and Father: Daily Emotional and Stressor Experiences in Adulthood. Journal of Developmental Psychology. Vol. 46. No. 06. 16511661.

Maulina, F. (2014). Tingkat Kemandirian Anak Usia Dini Ditinjau dari Status Kerja Ibu di Kecamatan Reban Kabupaten Batang. Belia: Early Childhood Education Papers, 3, 9-12. 
McKee, L., Roland, E., Coffelt, N., Olson, L. A., Forehand, R., Massari, C., et al. (2007). Hars Discipline and Child Problem Behaviors: The Role of Positive Parenting and Gender. Journal Families Violence, 22, 187-196.

Muflikhati, I., Hartoyo, Sumarwan, U., Fahrudin, A., \& Herien, P. (2010). Kondisi Sosial Ekonomi dan Tingkat Kesejahteraan Keluarga: Kasus di Wilayah Pesisir Jawa Barat. Jur. Ilm. Kel. \& Kons, 3, 1-10.

Nashih, U (1999). Pendidikan Anak Dalam Islam. Jilid 2. Jakarta: Pustaka Amani.

Nesneri, Y., \& Museliza, V. (2014). Motivasi Wanita Bekerja dan Pengaruhnya Terhadap Kontribusi Pendapatan Wanita dalam Membantu Pendapatan Keluarga di Kecamatan Marpoyan Damai Kota Pekanbaru. Marwab: Jurnal Perempuan, Agama, dan Jender. Vol.13, No.1, Hal. 74 - 103. http://ejournal.uinsuska.ac.id/index.php/marwah/issue/view/158

Network, N. I. (2003). Does Amount of Time Spent in Child Care Predict Socioemotional Adjustment During the Transition to Kindergarten? Child Development, 976-1005.

Nixon, E. (2010). Children's Perspectives on Parenting Styles and Discipline: A Developmental Approach. Dublin: The National Children's Strategy Research Series.

Parker, J.G., K.H., Price, J.M., DeRosier, E.M. (1995). Child Development and Adjusment: A Developmental Psychology Perspective. John Willey and Sons Inc.

Sahin, Fatma Tezel. (2014). Mother-Child Relation and Factors Affecting this Relation. International Journal of Science Culture and Sport, 2, 79-88.

Santrock, J. W. (2002). Life Span Development (Perkembangan Masa Hidup) Edisi Kelima. Terjemahan. Jakarta: Penerbit Erlangga.

. (2007). Perkembangan Anak Edisi Kesebelas. Jilid 2. Terjemahan. Jakarta: Penerbit Erlangga.

Shofiah, V. (2018). Gambaran Konsep Diri dan Attachment Ibu Pada Anak Kasus Narkoba. Marwah: Jurnal Perempuan, Agama, dan Jender. Vol.17, No.1, 20-31.

Thompson, R.A (2006). The development of the person: Social understanding, relationship, conscience, self. In N. Eisenberg (ed), Handbook of child psychology. Volume three: social, emotional, and personality development (pp.24-98). Sixth edition. New jersey, John Wiley \& Sons, Inc.

Werdiningsih, A. T., \& Astarani, K. (2012). Peran Ibu dalam Pemenuban Kebutuban Dasar Anak Terbadap Perkembangan Anak Usia Prasekolah. STIKES, 5 

(p-ISSN: 1412-6095|e-Issn: 2407-1587

Vol. 18, No. 2, 2019, Hal. 171-186 